\title{
Micropalaeontology of the Permian Marls of Merbah el Oussif (Jebel Tebaga, Tunisia) with special emphasis on the Ostracods
}

\author{
${ }^{1}$ F. LETHIERS, ${ }^{2}$ S. RAZGALLAH, ${ }^{3}$ J.P. COLIN \& ${ }^{4}$ D. VACHARD \\ 'Université Pierre et Marie Curie, Département de Géologie Sédimentaire, lab. de Micropal., T. 15, E4, place Jussieu, 75252 Paris Cedex \\ 05, France (URA 1315). \\ ${ }^{2}$ Faculté des Sciences, Département des Sciences de la Terre, Campus Universitaire, 1060 Tunis, Tunisie. \\ ${ }^{3}$ Esso Rep, 213 Cours Victor Hugo, 33321 Bègles, France \\ ${ }^{4}$ Université des Sciences et Techniques de Lille Flandre-Artois, U.F.R. Sciences de la Terre, 59655 Villeneuve d'Ascq Cedex, France.
}

\begin{abstract}
The Marls of Merbah el Oussif are part of the Permian series of the Jebel Tebaga of Médénine in Tunisia. They belong to the uppermost Murghabian, a stage intermediate between the Wordian and the Capitanian. These green marls were deposited in lows at the base of sponge bioherms. The sedimentation rate was high and the environment well oxygenated. The marls contain a relatively rich assemblage of isolated sponges, gastropods, smaller foraminifera, fusulinids, dasycladacean algae and ostracods. Amongst those, for the first time reported from the Permian of Tunisia, 14 species have been identified and one new species described, Bairdiac ypris postrectiformis sp. nov. The geographic and stratigraphic distribution of several species are discussed. This ostracod fauna indicates a shallow nearshore environment and suggests a western, not eastern connection between the Tethys and the Texas Sea.
\end{abstract}

\section{PRESENTATION OF THE JEBEL TEBAGA}

SERIES (S.R. \& D.V.)

The Jebel Tebaga is located $25 \mathrm{~km}$ north-west of the town of Médénine, in southern Tunisia. It outcrops in a group of hills $13 \mathrm{~km}$ long and $3 \mathrm{~km}$ wide, bordering the Djeffara plain (Fig. 1). The outcrop is a monoclinal series that reaches about 1000 metres in thickness and can be divided into five lithologic units (Fig. 1). From bottom to the top these are:

(a) Unit I, Dar Njana and Batun beni Zid includes intertidal or infratidal cross-bedded sandstones, a layer with Ottonosia oncolites, massive sandstones, and bioclastic limestones very rich in calcareous algae, Hemigordiopsis renzi Reichel, 1945, Yabeina syrtalis (Douvillé, 1934), Neosch- nagerina spp., all of the group of Neoschwagerina craticulifera (Schwager, 1883).

(b) Unit II, Jebel Tebaga sensu stricto, formed by Archaeolithoporella algal buildups and associated bioclastic limestones, often dolomitized.

(c) Unit III, Merbah el Oussif, consisting of laterally extensive green marls surrounding isolated sponge reefs. These marls are the object of this micropalaeontological study.

(d) Unit IV, Oudjah el Rhar, containing Archaeolithoporella algal buildups (Razgallah et al., 1987).

(e) Unit V, Halk el Djemmel, formed by ferruginous bioclastic limestones with the calcareous algae Permocalcu-

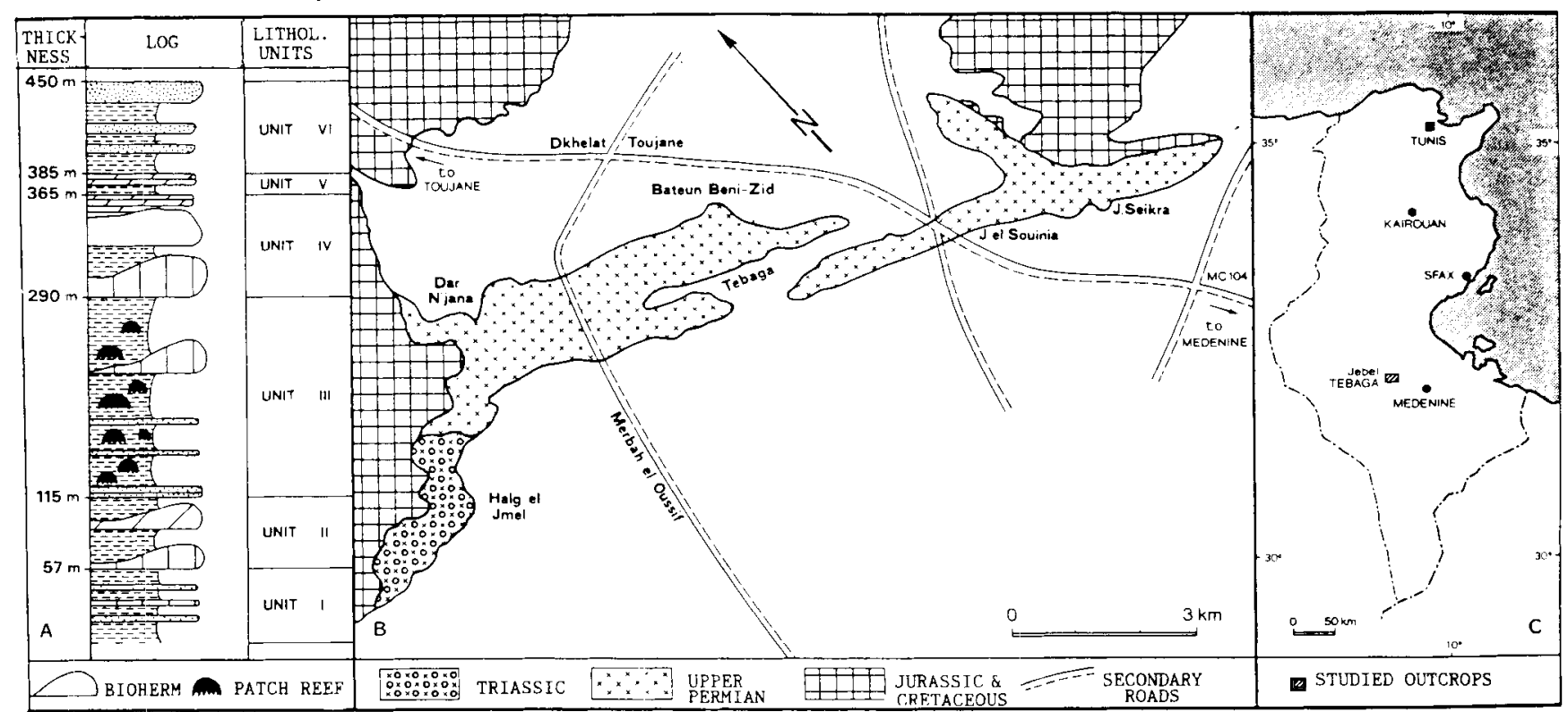

Fig. 1 Location map and synthetic stratigraphic column of Jebel Tebaga of Medenine. 
lus spp., Mizzia velebitana Schubert, 1908, and the fusulinid Yabeina syrtalis (Douvillé , 1934). At the top of this unit are dolomitized beds with common oncolites, Ottosonia laminata Twenhofel, 1919.

The eastern outcrops (Jebel Grous, Jebel es Souinnia, Chaabet Tarfaïa, Jebel es Seikra), rather tectonically disturbed by an important pre-Jurassic transform fault, probably belong to this last unit. These outcrops are rich in Dunbarula mathieui Ciry, 1948, Permocalculus spp.....

(f) Unit VI, Cheguimi (or Maasra), consists of a series of sandstones and tidal-flat clays with vertical borings and rare vertebrate tracks (Newell et al., 1976)

Several publications have discussed and illustrated the bioclastic composition of these levels: Glintzboeckel \& Rabaté (1964); Termier, Termier \& Vachard (1977), Driggs (1977), Vachard (1985), Khessibi (1985), Gargouri \& Vachard (1988), Vachard \& Razgallah (1988).

\section{AGE OF THE SERIES (D.V.)}

Based on the presence of fusulinids, the series has been attributed to the Late Permian (Douvillé, 1934). But only very recently, and for the first time, Khessibi (1985) questioned the precise age of the series. He concluded that units I to III were of Late Murghabian age because of the presence of Neoschwagerina and Yangchienia and that units IV and $V$ were of Dzhulfian age because of the presence of Yabeina, Reichelina and Codonofusiella.

With incorporation of new field, laboratory observations and recent modifications of the Permian chronostratigraphy (Vachard \& Razgallah, in press), we will improve on these datings (Fig. 2). First, the Dzhulfian does not directly overlie the Murghabian; the Midian stage, (introduced by Leven, 1981), although poorly defined, is situated between these two stages. Also the Reichelina and Codonofusiella, which are very rare and localised in the Jebel Tebaga, are known since the Murghabian; either the Later Murghabian (Vachard, 1980) or the Middle Murghabian (Lys et al., 1980). Finally, we have found Yabeina in the whole series and associated with Neoschwagerina at Bateun beni Zid.

Skinner \& Wilde (1967) also made this observation. Furthermore, they stated (p. 16) that in their samples, Neoschwagerina was present in levels situated above those with Yabeina.

As in Jebel Tebaga, Yabeina, Neoschwagerina, Yangchienia, as well as Reichelina and Codonofusiella, coexist in Turkey (Skinner, 1969).

All these elements lead us to the conclusion that all the outcrops of the Jebel Tebaga are of the same age, Murghabian, containing three biozones with Neoschwagerina, or Midian which markers are Yabeina and Lepidolina. Since the Lepidolina are totally absent in the Jebel Tebaga, we can exclude the Midian and suggest that the Jebel is of Murghabian age. The marker for the Late Murghabian, Neoschwagerina margaritae, is absent in the Jebel Tebaga but seems to be generally more developed in the eastern part of the Tethys. The three species (or sub-species) of
Neoschwagerina described in the Tebaga all belong to the Neoschwagerina craticulifera (Schwager, 1883) group, a species considered as a marker for the Murghabian in the Soviet Pamir. The whole assemblage is more advanced than the typical Middle Murghabian of Sosio in Sicily (Skinner \& Wilde, 1966). It contained only Neoschwagerina ex gr. craticulifera (Schwager, 1883) but no Yabeina, and Rugososchwagerina yabei (Staff, 1909) which is considered to be a rather reliable marker for the Middle Murghabian in the Tethys.

In the Murghabian stratotype, in the Soviet Pamir (Miklukho-Maclay, 1958, 1963; Dutkevitch, 1976; Leven, 1981), Neoschwagerina craticulifera (Schwager, 1883) is present in the Late Murghabian (Leven, 1967), whereas Yabeina appears only at the top of the stage.

If all these data are taken into consideration, we are tempted to recognise a zone with Neoschwagerina and with Yabeina at the top of the Murghabian for the Jebel Tebaga series. In order to place this zone in a bio- and chronostratigraphic framework, we used the Japanese succession proposed by Minato et al. (1978), the synthetic classification of Kozur (1977), the fusulinid zonation of Wilde (1975) for the U.S.A. and the official Soviet Union zonation, although obsolete and difficult the use. These correlations are presented in Figure 2. This table is in general agreement with the work of Nakazawa \& Kapoor (1977).

In the Western Tethys, the zone with Neoschwagerina and Yabeina is known in the Jebel Tebaga, Turkey, and probably in Yugoslavia (Kochansky, 1975; Kochansky \& Ramovs, 1978).

In conclusion, it should be noted that the series is more complete in boreholes. It can reach about $7000 \mathrm{~m}$ and contains possible Late Murghabian (zone with Dunbarula and Codonofusiella of Glintzboeckel \& Rabaté, 1964), Middle Murghabian (zone with "Polydiexiodina" of Glintzboeckel \& Rabaté, 1964: pl. 52-55,90-92; with common Afghanella and Polydiexodina) and possible Early Murghabian (zone with "Parafusulina" of Glintzboeckel \& Rabaté, 1964: pl. 89-108). There is a probable important hiatus since all the boreholes directly penetrated basal Permian and Late to Middle Carboniferous below the Murghabian (Glintzboeckel \& Rabaté, 1964: pl. 1-33).

The Dzhulfian may be present with characteristic Codonofusiella and Parareichelina (Glintzboeckel \& Rabaté, 1964: Pl. 56, Fig. 1 a-b and Pl. 58).

THE MARLS OF MERBAH EL OUSSIF (D.V. \& S.R.)

According to Khessibi (1985: p. 436-347), these green marls, channelised, extended about $3 \mathrm{~km}$ between sponge buildups. Their thickness varies from $250 \mathrm{~m}$ to $300 \mathrm{~m}$ and includes reefal buildups ranging in size from several tens to several hundreds of metres. Khessibi also reported numerous large size (several centimetres ) sponge debris.

After being washed for micropalaeontological analysis, these marls proved to be highly fossiliferous. Three main 


\begin{tabular}{|c|c|c|c|c|c|c|c|c|c|c|c|}
\hline \multicolumn{3}{|c|}{$\begin{array}{l}\text { CHRONO- } \\
\text { STRATICRAPHY }\end{array}$} & \multicolumn{2}{|c|}{$\begin{array}{c}\text { CENERALIZED } \\
\text { ZONATION SCHEME }\end{array}$} & \multirow{3}{*}{\multicolumn{2}{|c|}{$\begin{array}{c}\begin{array}{c}\text { TUNISIA } \\
\text { (this paper) }\end{array} \\
\begin{array}{c}\text { Tebaga borehole } \\
\text { Globivalvulina }\end{array}\end{array}$}} & \multirow{3}{*}{\begin{tabular}{|c|} 
JAPAN \\
(MINATO et al. 1978) \\
- \\
$\begin{array}{c}\text { Palaeofusulina } \\
\text { sinensis + } \\
\text { Colaniella parva }\end{array}$ \\
\end{tabular}} & \multicolumn{2}{|c|}{ KOZUR 1977} & $\left\{\begin{array}{c}\text { U.S.A. } \\
\text { (WILDE 1975) }\end{array}\right.$ & U.S.S.R \\
\hline \multirow{2}{*}{\multicolumn{2}{|c|}{ DORASHAMIAN }} & \multirow{3}{*}{ 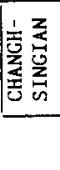 } & \multirow{5}{*}{ 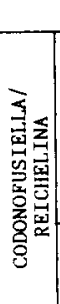 } & \multirow[b]{3}{*}{ PALAEOFUSULINA } & & & & \multirow{3}{*}{ 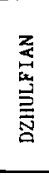 } & \multirow{3}{*}{\begin{tabular}{|l}
$\begin{array}{c}\text { DORASHA- } \\
\text { MIAN }\end{array}$ \\
BAISALIAN
\end{tabular}} & \multirow{4}{*}{ OCHOAN } & \multirow{5}{*}{ TATARIAN } \\
\hline & & & & & & & & & & & \\
\hline \multicolumn{2}{|r|}{ DZHULFIAN } & & & & \multicolumn{2}{|c|}{$\begin{array}{c}\text { Tebaga borehole } \\
\text { Parareichelina- } \\
\text { Codonofusiella }\end{array}$} & $\begin{array}{l}\text { Palaeofusulina simplex } \\
+ \text { Colaniella minima }\end{array}$ & & & & \\
\hline \multirow{2}{*}{\multicolumn{3}{|c|}{ "MIDIAN" }} & & LEPIDOLINA & \multirow{2}{*}{\multicolumn{2}{|c|}{ ? CHEGUIMI }} & $\begin{array}{c}\text { Lepidolina kumaensis } \\
+\mathrm{L}^{\mathrm{a}} \text { multiseptata }\end{array}$ & \multicolumn{2}{|c|}{ ABADEHIAN } & & \\
\hline & & & & $\begin{array}{l}\text { YABEINA- } \\
\text { LEPIDOLINA }\end{array}$ & & & $\begin{array}{l}\text { Yabeina globosa + } \\
\text { Lepidolina } \\
\text { multiseptata }\end{array}$ & \multicolumn{2}{|c|}{ CAPITANIAN } & \multirow{3}{*}{ GUADALUPIAN } & \\
\hline \multirow{4}{*}{$\begin{array}{l}\mathrm{M} \\
\mathrm{U} \\
\mathrm{R} \\
\mathrm{G} \\
\mathrm{H} \\
\mathrm{A} \\
\mathrm{B} \\
\mathrm{I} \\
\mathrm{A} \\
\mathrm{N}\end{array}$} & \multicolumn{2}{|c|}{ Uppermost } & \multicolumn{2}{|c|}{ NEOSCHWAGERINA-YABEINA } & \multicolumn{2}{|r|}{ Tebaga outcrops } & $" N^{a+1}$ douvillei & \multirow{4}{*}{\multicolumn{2}{|c|}{ WORDIAN }} & & \multirow[t]{4}{*}{ KAZANIAN } \\
\hline & \multicolumn{2}{|c|}{ Upper } & \multicolumn{2}{|c|}{$\begin{array}{c}\mathrm{N}^{\mathrm{a}} \text { craticulifera- } \\
\mathrm{N}^{\mathrm{a}} \text { margaritae }\end{array}$} & & $?$ & $\mathrm{~N}^{3}$ margaritae & & & & \\
\hline & \multicolumn{2}{|c|}{ Middle } & \multicolumn{2}{|r|}{$N^{a}$ craticulifera } & & $\begin{array}{l}\text { Tebaga borehole } \\
\text { lanella-Eopolydiexodina }\end{array}$ & $\mathrm{N}^{\mathrm{a}}$ craticulifera & & & $\begin{array}{l}\text { MIDDLE } \\
\text { GUADALUPIAN }\end{array}$ & \\
\hline & \multicolumn{2}{|c|}{ Lower } & \multicolumn{2}{|r|}{$N^{a}$ simplex } & & $\begin{array}{l}\text { Tebaga borehole } \\
\text { Parafusulina }\end{array}$ & $\begin{array}{l}\mathrm{N}^{\mathrm{a}} \text { simplex }+ \\
\text { Parafusulina } \\
\text { kaerimizensis }\end{array}$ & & & $\begin{array}{l}\text { EARLY } \\
\text { GUADALUPIAN }\end{array}$ & \\
\hline
\end{tabular}

Fig. 2 Correlation table of several Upper Permian Stratigraphic scales.

groups of microfossils are common in the washed residues:

(a) Unidentified gastropods;

(b) green and red algae: Permocalculus plumosus Elliott, 1955, Permocalculus tenellus (Pia, 1937), Mizzia velebitana Schubert, 1908, Mizzia yabei (Karpinsky, 1908), Velebitella triplicata Kochansky, 1964;

(c) foraminifera: dominated by Climacammina valvulinoides Lange, 1925, with Globivalvulina graeca Reichel, 1946 and the fusulinid Neoschwagerina ex gr. craticulifera (Schwager, 1883) and Dunbarula mathieui Ciry, 1948;

(d) ostracods, which will be discussed in more details in the next chapters.

Marly layers are rather frequent in the Jebel Tebaga series. These are always associated with sandstones and very shallow-water limestones, which are very rich in photophile algae. The Marls of Merbah el Oussif are situated between sponge buildups. Also, channelised sandstones are often present between the algal buildups of units II and IV.

Therefore, this is not a succession between "deeper water" marls, "shallow water" reefal limestones and beach sandstones, but clastic influxes deposited between the reefs during lateral migration of distributory channels. We can consider the sandstones as being deposited by distributory channels and the marls as corresponding to interdistributory areas. An alternative interpretation is that the sandstones are proximal deposits and the marls are distal sediments deposited close to the mud-line of the deltaic lobes (Blanc, 1982).

The water-depth during the deposition of these marls was most likely to have been between a few metres and a few tens of metres. They seem to be a bionomic equivalent of the coastal terrigenous muds, which have been intensively studied in recent and fossil sediments (Peres \& Picard, 1964; Masse, 1976; Plaziat, 1984).

Dasycladacean algae, sessile forms growing on hard substrate, could have developed in situ since they can grow on isolated pebbles in a muddy environment (observation by D.V. in recent environments). Some ostracods, gastropods and small foraminifera could have been epiphytal on these algae. On the other hand, the sponges, which are broken and of large size, most likely to have been transported. Such mixtures have been observed in the Paleocene "Turitella Marls" in southern France and northern Spain. Plaziat (1984) interpreted those as: (a) a mixing of decantation autochtonous deposits and shelly mud-flows during major storms; (b) bay and prodelta sediments deposited between littoral, often reefal, limestones and marls with nummulitids (larger foraminifera). Such a model seems to be applicable to the Marls of Merbah el Oussif.

The green colour of the marls clearly indicates that the environment was well oxygenated. The sedimentation rate was high as indicated by the scarcity of bioturbation and of endobiontic organisms.

\section{OSTRACODS FROM THE MARLS OF MERBAH EL OUSSIF (F.L \& J.-P.C.)}

In this study we recognised for the first time in the Permian of Tunisia (Bismuth, 1984), 14 species of ostracods. This record is not necessarily complete since several fragments of other species are present, believed to belong to the superfamily Kirkbyacea and to the genus Buregia? Termier et al. (1977), reported and illustrated thin sections of specimens assigned to the genus Cryptophyllus in the Batun Beni zid Unit. Therefore, complementary studies appear to be necessary. However, some biostratigraphical, paleoecological and paleogeographical conclusions can be proposed and a new species described.

The species collected are listed below; plate and figure numbers are given; figured specimens are deposited in the collection of the Laboratoire de Micropaléontologie, Université, Paris VI). 
Amphissitidae Knight, 1928

Amphissites cf. A. centronotus (Ulrich \& Bassler, 1906): Pl. 1, fig. 1.

Hollinellidae Bless \& Jordan, 1971

Hollinella $(H$.) herrickana (Girty, 1909): PI. 1, figs. 2-4; Hollinella $(H$.$) menardensis Harlton, 1929: Pl. 1, fig. 5$.

Serenididae Rozhdestvenskaja, 1972

"Cavellina" (= Serenida) cf. "C." bisecta sensu Cooper (1946): PI. 1, figs. 6-7;

Sargentina whitei (Bradfield, 1935): Pl. 1, figs. 8-9; Pl. 2, fig. $1-2$.

Cavellinidae Egorov, 1950

Sulcella sulcata Coryell \& Sample, 1932: Pl. 2, fig. 3;

Sulcella cf. S. rotunda (Cooper, 1946): Pl. 2, fig. 7.

Bairdiocyprididae Shaver, 1961

Silenites cf. S. grayi (Crespin, 1945): Pl. 3, fig. 5.

Bairdiidae Sars, 1988

"Bythocypris" (= Bairdiacypris) shideleri sensu Schneider (1948): Pl. 3, fig. 4;

Bairdiacypris deloi Bradfield, 1935: Pl. 2, fig. 9;

Bairdiacypris postrectiformis sp. nov.: Pl. 2, figs. 4-6, 8; Pl.

3, fig. 3;

Bairdiacypris praewangi Kozur, 1985: Pl. 3, figs. 1-2;

Bairdia consimilis Gusseva, 1971: Pl. 3, figs. 6-7;

Bairdia cf. B. mucronulata Gusseva, 1971: Pl. 3, fig. 8.

Although marine Permian ostracods are relatively well known in the North American shelf, they have been rarely studied in Europe, Asia and Australia. In North Africa, very few species have been published. In north east Egypt, Adindani et al. (1977) reported Knightina hassleri Kellett, 1933, Bythocypris osagensis Kellett, 1935 and Healdia ciscoensis Harlton, 1927 in the basal Permian and Wasfi et al. (1977) also mentioned Healdia parallela Kellett, 1935.
In Israel, 28 species have been recently reported in the Late Permian (Gerry et al., 1987); several are similar to those described by Kozur (1985) in Hungary and by Wang (1978) in China. In Oman, amongst 18 marine species from a probable Late Permian, 13 are related to North American species (F.L. unpublished report).

Until now the stratigraphic range of the Late Carboniferous and Permian ostracod species having wide geographical distribution could not be accurately determined. For this reason, long distance correlations are only approximate. The Marls of Merbah el Oussif have been dated as uppermost Murghabian age by means of fusulinids. The discovery of this ostracod fauna is important because it improved our knowledge of their stratigraphic distribution. As a result of our work, we are able to extend the range of several species upwards into the Permian (Fig. 3). In particular, the Late Carboniferous species such as Bairdiacypris deloi Bradfield, 1935, Hollinella (H.) menardensis Harlton, 1929, Sargentina whitei (Bradfield, 1935) and Sulcella sulcata Coryell \& Sample, 1932, are now found to extend up into the Late Permian with total ranges of about $50 \mathrm{My}$. A tendency toward long duration of ostracod species during the Late Carboniferous and the Permian is confirmed. For long distance correlations, it will be necessary therefore to use intervalzones. This type of zonation has recently been proposed for the Late Carboniferous and Early Permian of Texas (Melnyk \& Maddocks, 1988b).

Some paleoecological interpretations can be proposed for the sedimentary environment of the Marls of Merbah el Oussif. The ostracod genera encountered are known to be benthic, shallow-marine forms, living near the water-substratum interface or on plants. The ecological requirement of some of these species has been established by detailed studies on the relationship between facies and species in the Early Permian of Texas (Melnyk \& Maddocks, 1988a) and Kansas (Peterson \& Kaesler, 1980; Costanzo \& Kaesler, 1987). For example, Amphissites centronotus (Ulrich \& Bassler, 1906) is abundant off shore and becomes rare as it is the case here, nearshore. It has also been found associated

\section{Explanation of Plate 1 \\ All specimens are from the Merbah el Oussif Marls (Jebel Tebaga, Tunisia), Late Permian (Late Murghabian).}

Fig. 1 Amphissites cf. A. centronotus (Ulrich \& Bassler, 1906), right lateral view (x 100), sample 205, P6M 10000.

Fig. 2 Hollinella (Hollinella) herrickana (Girty, 1909); fig. 2a, male right lateral view; fig. 2b, male carapace, dorsal view (x 100), sample H 11, P6M 10001.

Fig. 3 Hollinella (Hollinella) herrickana (Girty, 1909); fig. 3a ? female, right lateral view (x50); fig. 3b, same specimen, detail postero-dorsal area (x 100), sample H 11, P6M 10002.

Fig. 4 Hollinella (Hollinella) herrickana (Girty, 1909), ? female carapace, ventral view (x50), sample H 11, PM 10003.

Fig. 5 Hollinella (Hollinella) menardensis Harlton, 1929, left valve, lateral view (x75), sample 205, P6M 10004.

Figs. 6-7 "Cavellina" cf. C. bisecta sensu Cooper, 1946; fig. 6, right valve, interior view (x50), sample 224, P6M 10005; fig. 7 , right valve, lateral view (x50), sample 224, P6M 10006.

Figs. 8-9 Sargentina whitei (Bradfield, 1935); fig. 8, heteromorph dorsal view (x75), sample 224, P6M 10007; fig. 9, heteromorph left view (x85), sample 228, P6M 10008. 


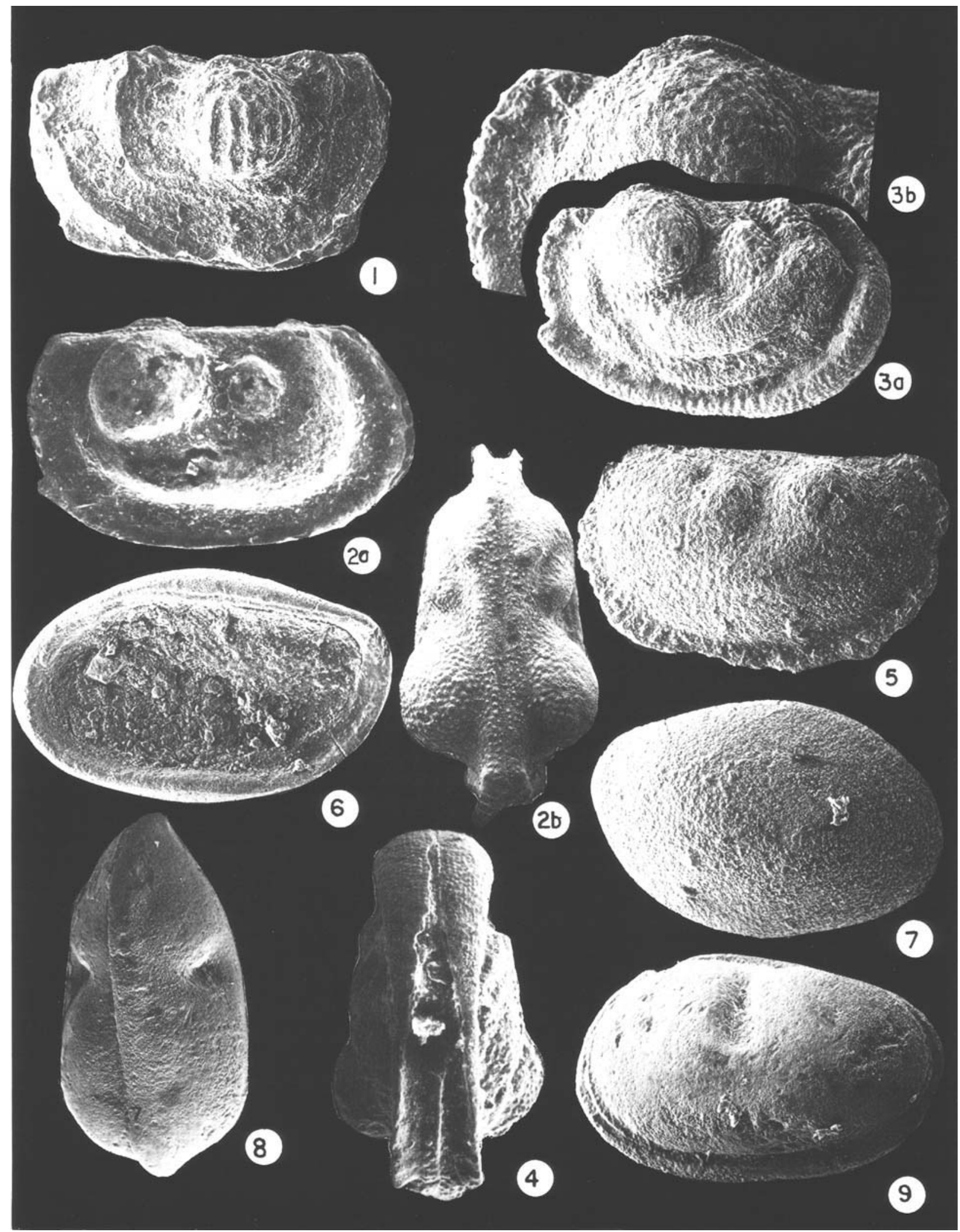


Lethiers, Razgallah, Colin \& Vachard

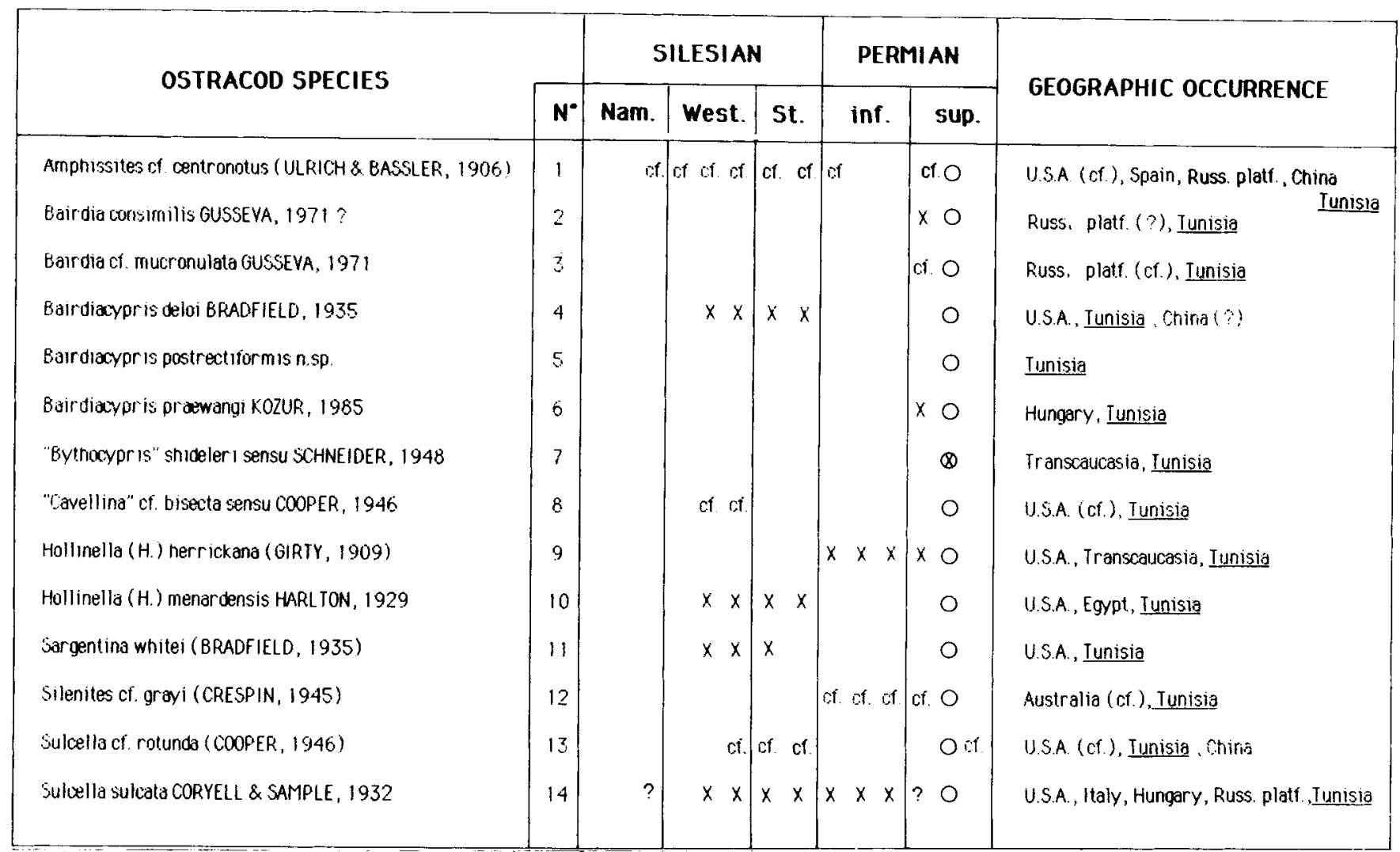

Fig. 3 Stratigraphic and geographic occurrences of the Jebel Tebaga ostracod species.

with probable reworked freshwater Carbonita. Sulcella sulcata Coryell \& Sample, 1932 often corresponds to quiet lagoonal environments, with normal to brackish salinities. Bairdiacypris deloi Bradford, 1935 belongs to the nearshore Bairdiacypris group of species. Large species of Hollinella, with developed adventral structure (velum), can characterise environments such as interdistributary bay prodelta and interdeltaic embayment lagoons. Species of Bairdia, which are normally abundant in carbonate open marine environments, are relatively rare. Few taphononic characters can be used. Carapaces of the species of Hollinella are often fragmented and the species Bairdiacypris postrectiformis sp. nov. shows only adults and the last larval stage (Fig. 4). These characters indicate either a high energy biocoenosis, or a thanatocoenosis, following Whatley $(1983,1988)$ and Brouwers (1988). However, transportation was limited since most individuals of the latter species are represented by closed carapaces indicating a soft substratum and a relatively high sedimentation rate (Oertli, 1971).

In conclusion, the ostracod fauna from the Marls of Merbah el Oussif shows that the paleoenvironment was shallow marine, between 1 and about 15 metres deep, with normal salinity, (slight variations in salinity are possible) and limited and localised bottom currents.

\section{Explanation of Plate 2}

All specimens are from the Merbah el Oussif Marl (Jebel Tebaga, Tunisia)Late Permian (Late Murghabian).

Figs. 1-2 Sargentina whitei (Bradfield, 1935); fig. 1, heteromorph right valve interior view (x90), sample 224, P6M 10009; fig. 2a, tecnomorph right lateral view (x90), sample 224, P6M 10010; fig. 2b, tecnomorph dorsal view (x90), sample 224, P6M 10010.

Fig. 3 Sulcella sulcata Coryell \& Sample, 1932, tecnomorph specimen; fig. 3a, carapace, left lateral view (x95); fig. 3b, carapace, dorsal view (x95), sample 228, P6M 10012.

Figs. 4-6,8 Bairdiacypris postrectiformis sp. nov., sample H 11; fig. 4, left lateral view (x 60), paratype, P6M 10016; fig. 5, carapace, ventral view (x70), paratype, P6M 10015; fig. 6, carapace, right lateral view (x70), holotype, P6M 10017; fig. 8, carapace, dorsal view (x70), paratype, P6M 10019.

Fig. 7 Sulcella cf. S. rotunda (Cooper, 1946), heteromorph right view (x 70), sample H 11, P6M 10011.

Fig. 9 Bairdiacypris deloi Bradfield, 1935, sample H5A, P6M 10024; fig. 9a, carapace, right lateral view (x55); fig. 9b, carapace, dorsal view $(\mathrm{x} 65)$. 


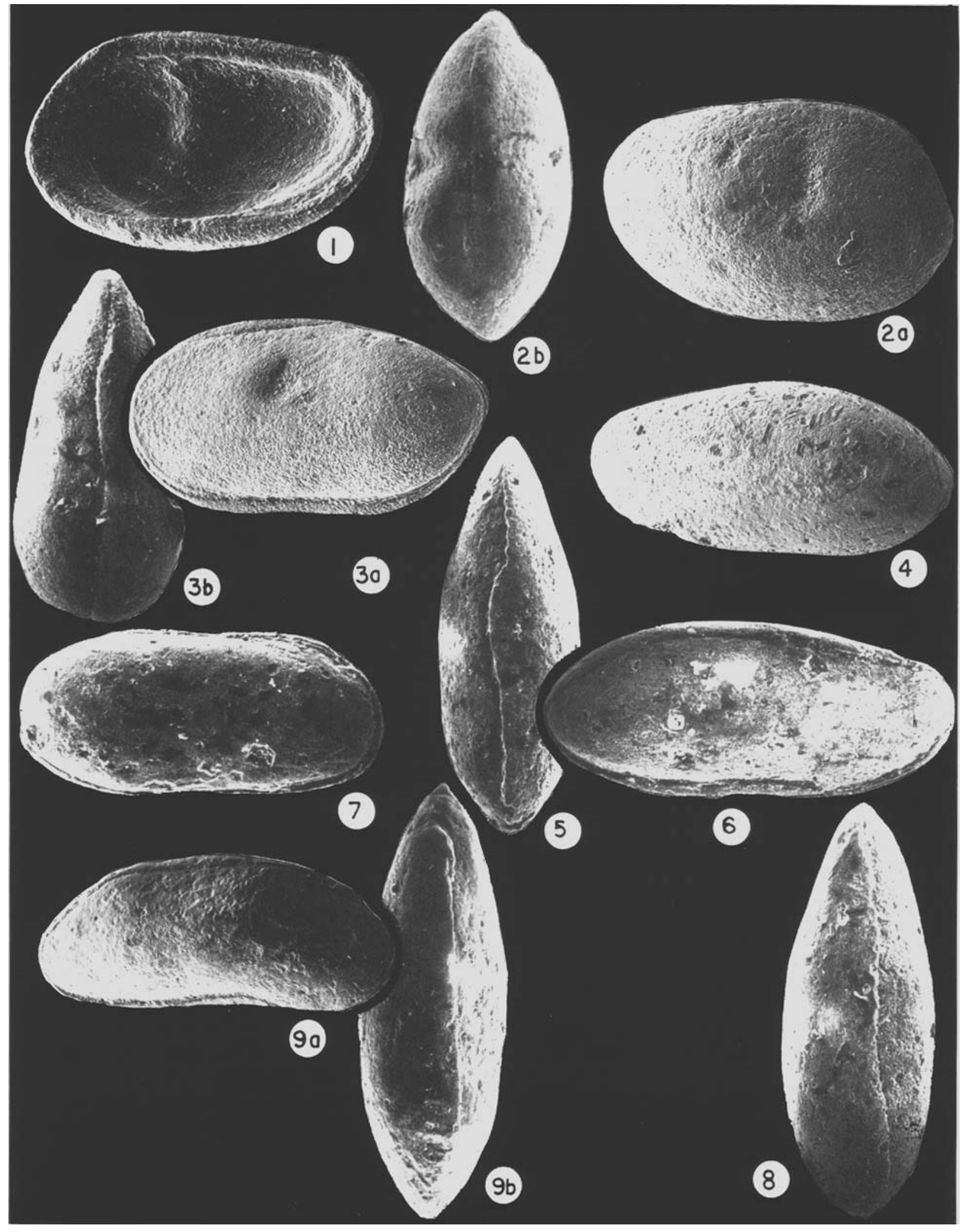




\section{PALEOGEOGRAPHIC AND BIOSTRATIGRAPHIC REMARKS (D.V., J. -P.C., F.L.)}

Fusulinids, smaller foraminifera and algae of the Jebel Tebaga seem to present a certain provincialism, which confine them to Tunisia, Sicily, Yugoslavia and Turkey. The ostracod microfauna is rather peculiar. Local ecological control however can limit the lateral distribution of some taxa. In fact, Tethyan faunas are present more or less from one end to the other of the Tethys, from Tunisia to Japan and Southern China.

What is the place of the ostracods in this Tethyan realm? Gerry et al. (1987) recently published a study on this subject which warrants some discussion. In Israel the Permian is only known from subsurface, essentially in the Negev, and the major study from this area was carried out about 20 years ago (Weissbrod, 1969). However, Gerry et al. (op. cit.) did not differ significantly from the conclusions of the earlier work. The Early Permian is represented by the Sa'ad Formation about which we have no comments. The Late Permian is represented by the Arqov Formation. According to Weissbrod $(1969$, p.7), this formation has yielded Late Carboniferous ostracods and Late Permian foraminifera, Hemigordiopsis ef. renzi Reichel, 1945 (identified by M. Hamaoui). Weissbrod's illustrations (P1. 1, figs. 7-11) leave no doubt regarding the misidentification; the specimen illustrated is, in fact, Pilammina densa Pantic, 1965, which is characteristic of the Middle-Late Anisian (Early Triassic). This does not necessarily invalidate the attribution to the Late Permian since contamination by cavings is always possible in boreholes. The Arqov Formation has been correlated by Gerry et al. with the Khuff Formation in Saudi Arabia (Table 1, p. 199). This formation has been recently studied by one of the authors (D.V.). The age is Dzhulfian, Dorshamian and Early Scythian, therefore Permo-Triassic. In conclusion, the Arqov Formation is poorly dated and is unlikely to be synchronous with the Jebel Tebaga outcrop.

Gerry et al. (1987, p. 200) pointed out that except in Italy, Permian ostracods have not been described from the Mediterranean realm and the Middle East. The Italian level, described by Pasini (1981) belongs to the upper part of the Bellerophon Formation of the Dolomites, which would correspond to the Dorshamian (Noe, 1987) or even the Early Scythian according to Giacobbe (1987).
The only fusulinid reported in Israel, Codonofusiella sp. (Gerry et al., 1987), cannot give a more precise age than Late Murghabian to Early Dzhulfian. A very similar taxon, Paradoxiella can range higher into the Late Dzhulfian (Lys et al., 1980).

We think that the Israeli ostracod assemblage with Italogeisina-Hungarogeisina is of Dzhulfian-Dorashamian age, contemporaneous with the Italian Bellerophon limestones, but more recent than the Jebel Tebaga levels. Few Israeli species are in common with those described from the Bukk area in Hungary (Kozur, 1985), dated as Abadehian, or those of Late to latest Permian from Southern China (Wang, 1978). The Israeli authors mentioned other affinities with the Middle Permian of Japan and the Early Triassic of Pakistan. Therefore, the paleogeographical correlations proposed by Gerry et al., based on non synchronous datings are not strictly reliable.

A more peculiar affinity of the ostracod fauna of the Jebel Tebaga deserves further attention. It is necessary to extend the relations with the Russian platform on one side, with Texas and Oklahoma on the other side. In fact, amongst the 14 species recognised in the Jebel Tebaga, 5 are already known in the U.S.A. and 3 are very closely related to U.S. species. This tendency confirms the affinities formerly evoked for Egypt and Oman. At least 10 Permian species from Texas and Oklahoma are reported from the Russian platform (see for example Beloussova, 1962 and Urasina \& Zekina, 1970). Most authors consider that the Jebel Tebaga is the most western marine Permian outcrop of the Tethys and that this western extremity is totally separated from the North American marine platform by a laterally extensive continental area (Termier, Termier \& Vachard, 1977; Termier \& Termier, 1979; Ziegler et al., 1979; Ross \& Ross, 1985). We therefore agree that a connection existed between the two margins of the present Pacific Ocean.

The comparisons between "Tethyan" and "Occidental", i.e. North-American provinces, based on Fusulinid associations was first elaborated by Wilde (1975). Wilde showed that greater differences existed between the two provinces during the period equivalent to the Late Murghabian. He distinguished a Yabeina-Neoschwagerina population in the Tethys and a Polydiexodina population in the U.S.A. Once more, additional precise analyses need to be carried out

\section{Explanation of Plate 3}

All specimens are from the Merbah el Oussif Marls (Jebel Tebaga Tunisia),Late Permian (Late Murghabian)

Figs. 1-2 Bairdiacypris praewangi Kozur, 1985; fig. 1, carapace, right view (x 60), sample 224, P6M 10013; fig. 2a, left view (x60), sample 224, P6M 10014; fig 2b, carapace, dorsal view (x 60), sample 224, P6M 10014.

Fig. 3 Bairdiacypris postrectiformis sp. nov. carapace, right lateral view (x65), paratype, P6M 10018;

Fig. 4 "Bythocypris" shideleri (Delo) sensu Schneider, 1948, left lateral view (x55), sample H5a, P6M 10020.

Fig. 5 Silenites cf. S. grayi (Crespin, 1945), carapace, right lateral view (x 80), sample 224, P6M 10021.

Figs. 6-7 Bairdia consimilis Gusseva, 1971; fig. 6a, carapace, right lateral view (x90), sample 228, P6M 10022; fig. 6b, carapace. dorsal view (x90), sample 228, P6M 10022; fig. 7, carapace, right lateral view (x 75), sample 224, P6M 10023;

Fig. 8 Bairdia cf. B. mucronulata Gusseva, 1971, carapace, right lateral view (x70), sample 224, P6M 10025. 


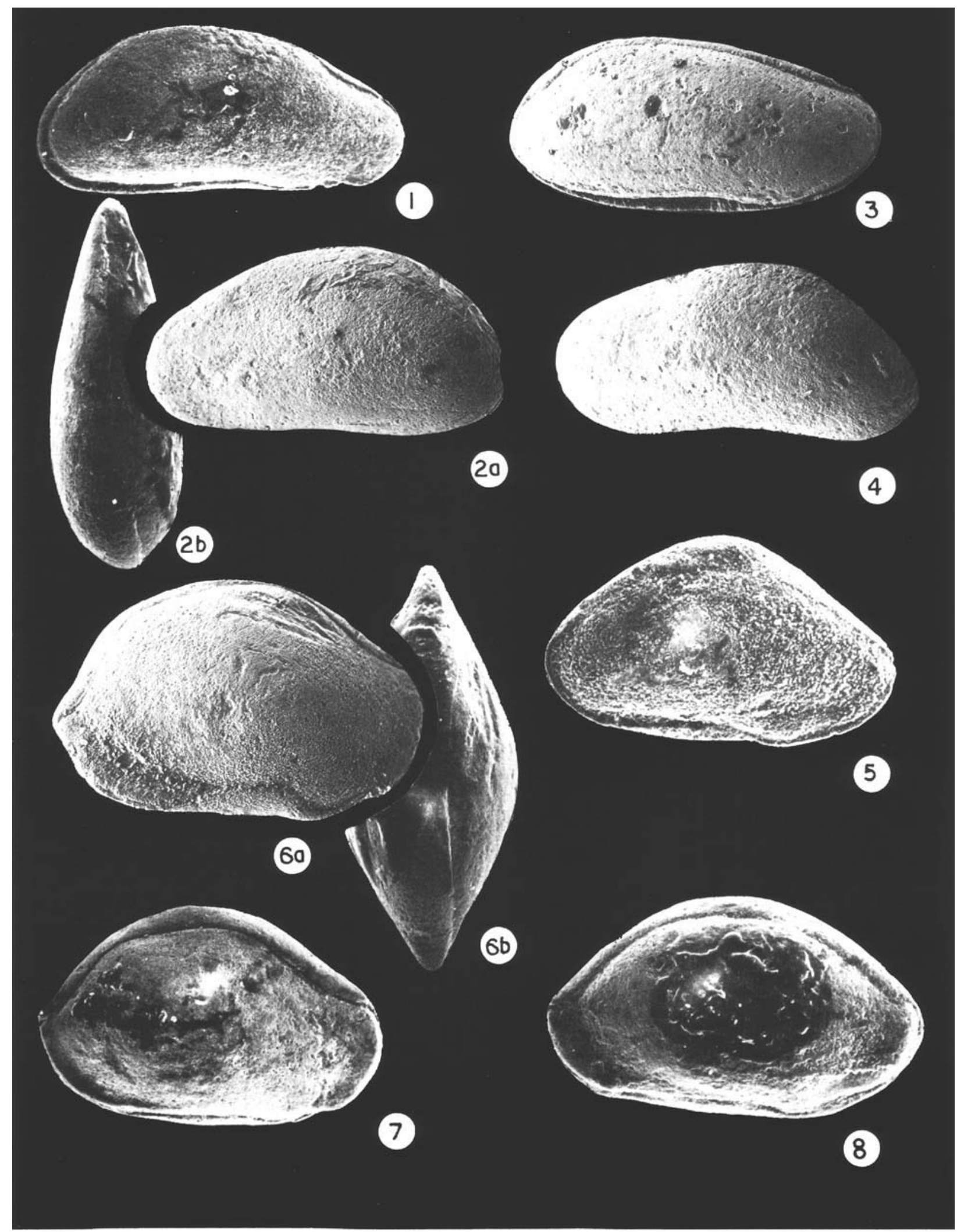


before reliable biostratigraphical and paleogeographical correlations can be made.

\section{OSTRACOD SYSTEMATICS (F.L.)}

This chapter is limited to the description of one new species Bairdiacypris postrectiformis sp. nov. Catalogue nos. (P6M) refer to the collection of the Laboratoire de Micropaléontologie, Université Paris VI.

Family Bairdiidae Sars, 1988

Genus Bairdiacypris Bradfield, 1935 (see Sohn, 1983, p.231)

Bairdiacypris postrectiformis sp. nov. (P1. 2, figs. 4-6,8; P1.3, fig. 3)

Derivation of name. After the phyletic lineage of Bairdiacypris rectiformis (Shaver, 1959).

Diagnosis: A species of the genus Bairdiacypris with the following characters: ventral margin short and straight; antero-dorsal margin long, straight or slightly concave; rounded part of the anterior margin short, in an upwards position; outline elongated and anteriorly pointed in dorsal view.

Holotype. One carapace, Pl.2, fig. 6, P6M 10017. Paratypes. Four carapaces, Pl.2, figs. 4,5,8, P6M 10015, 10016, and 10019; P1.3, fig. 3, P6M 10018.

Type-locality. Jebel Tebaga, Tunisia.

Type-level. Marls of Merbah el Oussif, Late Permian, uppermost Murghabian.

Material. 40 specimens from samples H11, H54, 205, 224.

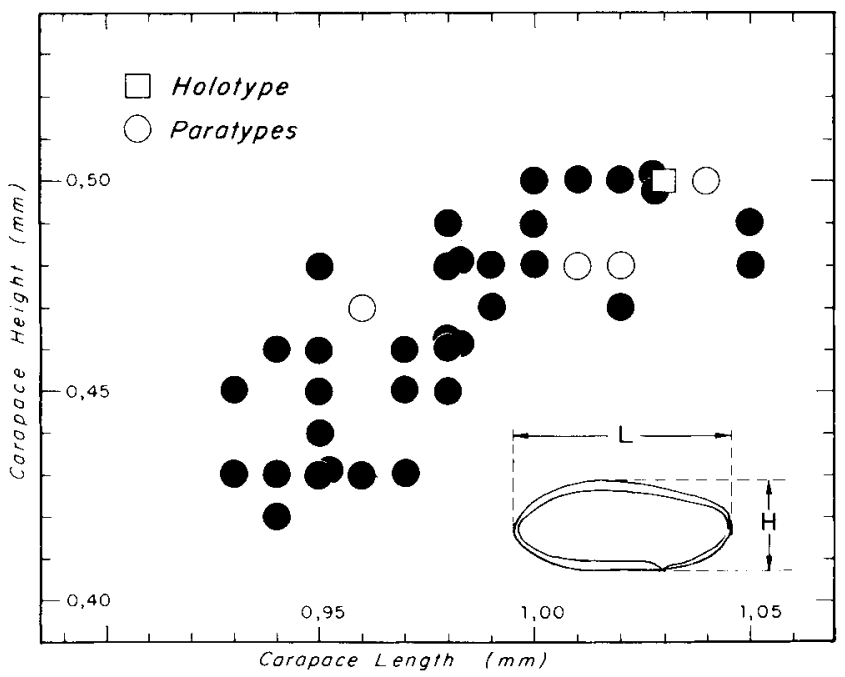

Description. Carapace ovoid with short dorsal margin, slightly convex to straight, parallel to the ventral margin, short and straight. Antero-dorsal margin straight to slightly concave and inclined towards the anterior. Anterior margin with its rounded part short and situated upwards, near or slightly above the mid-height, giving a narrow elongate anterior part. Antero-ventral margin strongly convex. Posterior margin as a short rounded narrow angle slightly below the mid-height. Weak overlap of the left valve over the right valve along the anterior and anteroventral margins, marked along the antero-dorsal and dorsal margins and more important along the postero-dorsal margin. Distinct ventral overlapping lip, near or slightly in front of the mid-length. In dorsal view, fusiform outline with maximum thickness near or slightly behind the mid-length; lateral sides sometimes flattened; anterior end representing about $1 / 3$ of the length with sides sub-straight; posterior end short with sides slightly convex. Smooth surface.

Dimensions. see Fig. 4.

Length Height Width (mm)

Holotype (P6M 10017; Pl.2, fig. 6) $1.03 \quad 0.50 \quad 0.43$ Paratype (P6M 10015; Pl.2, fig. 5) $0.96 \quad 0.47 \quad 0.40$ Paratype (P6M 10016; Pl.2, fig. 4) $1.04 \quad 0.50 \quad 0.45$ Paratype (P6M 10018; P1.3, fig. 3) $1.01 \quad 0.48 \quad 0.43$ $\begin{array}{llll}\text { Paratype (P6M 10019; Pl.2, fig. 8) } & 1.02 & 0.48 & 0.40\end{array}$

Remarks. B. postrectiformis sp. nov. possesses a general morphology similar to several species from the Late Carboniferous-Early Permian of the southern and central U.S.A. such as Bairdiacypris wharthini (Bradfield, 1935) and Bairdiacypris acetalata (Coryell \& Billings, 1932) (see synonymies in Sohn, 1961). Our species differs by the diagnostic characters and especially by its straight ventral margin and the narrow elongate anterior part in lateral view. Bairdiacypris postrectiformis sp. nov. belongs to the phyletic lineage of Bairdiacypris rectiformis (Shaver, 1959) (see synonymy in Sohn, 1983, p. 124) of the Westphalian (Akotan) of Illinois and Ohio. Nevertheless, it differs by the shorter rounded part of the anterior margin and a more accentuated overlap along the postero-dorsal margin, visible especially in dorsal view. Also, our species is similar to Bairdiacypris obuncus Beloussova, (1965) from the basal Triassic of Transcaucasia; it differs by its straight ventral margin and its less flattened dorsal outline. The lateral outline of our species also is reminiscent of Bairdiacypris parva (Wang, 1978) from the Late Permian of China. It differs by its dorsal outline showing a long and acuminate anterior.

Distribution. Only known from the type-locality and typehorizon.

\section{ACKNOWLEDGEMENTS}

We would like to express our sincere thanks to Dr. T. Davies (Houston, Texas, U.S.A.) for his critical reading and correction of the English text and Dr. H. Bismuth (Tunis, Tunisia) for his judicious comments.

Manuscript received October 1988. Manuscript accepted August 1989. 


\section{REFERENCES}

Adindani, A., Cherif, O.H. \& Eissa, R.A. 1977. Contribution of the study of some Upper Paleozoic Ostracoda from the Rod El Hamal Formation, Eastern Desert, Egypt. Ann. Mines Géol., Tunis, 28, 5-19.

Beloussova, Z.D. 1962. Upper Permian ostracods from the central and northeastern Russian platform. In: Stratigrafitcheskie sxaemy paleozoiskixa otlojenii. Permskaya sistema, 139-146 (in Russian).

Beloussova, Z.D. 1965. Class Crustacea. In: Evolution and succession of organisms at the Paleozoic-Mesozoic boundary. Trudy paleont. Instit. (Akad. Nauk SSSR), 108, 254-265 (in Russian).

Bismuth, H. 1984. Les ostracodes de Tunisie: recensement bibliographique. Bull. Centres Rech. Explor. -Prod. ElfAquitaine, 8, 2, 425-534.

Blanc, J.J. 1982. Sédimentation des marges continentales, actuelles et anciennes, 159 pp., Masson, Paris.

Brouwers, E.M. 1988. Sediment transport detected from the analysis of ostracod population structure: an example from the Alaskan continental shelf. In: De Deckker, P., Colin, J. -P. \& Peypouquet, J. -P. (edits.), Ostracoda in the Earth Sciences, 231-244, Elsevier.

Cooper, C.L. 1946. Pennsylvanian ostracodes of Illinois. Illinois geol. Surv., 70, 1-177.

Costanzo, G.V. \& Kaesler, R.L. 1987. Changes in Permian marine ostracode faunas during regression, Florena shale, northeastern Kansas. J. Paleont., 61, 1204-1215.

Douvillé, H. 1934. Le Permien marin de l'extrême-sud Tunisien; II: les fusulinidés de la Tunisie. Mém. Serv. Carte géol. Tunisie, 1, 1, 75-90.

Driggs, A. F. 1977. The petrology of three Upper Permian bioherms, southern Tunisia. Brigham Young Univ. geol. Stud., 24, 1, 37-53.

Dutkevich, G.A. 1967. Few species of Yabeina from the Upper Permian of the southeastern Pamir. Paleont. $Z$ (Akad. Nauk SSSR), 1, 18-21.

Gargouri, S. \& Vachard, D. 1988. Sur Hemigordiopsis et d'autres foraminiféres porcelanés du Murghabien du Tebaga (Permien supérieur de Tunisie). Benthos 86, Genève: 57-68.

Gerry, E., Honingstein, A., Derin, B. \& Flexer, A. 1987. Late Permian ostracodes of Israel. Taxonomy, distribution, and paleogeographical implications. Senckenh. Lethaea, $68, \mathbf{1} / \mathbf{4}, 197-223$.

Giaccobe, B. 1987. Foraminiferi di facies evaporitiche (Formazione a Bellerophon, Permiano sup., Dolomiti). Ann. Univ. Ferrara, 9, 3, 49-57.

Glintzboeckel, C. \& Rabaté, J. 1964. Microfaunes et microfaciès du Permo-Carbonifère du Sud-Tunisien, 45 pp., E.J. Brill, Leiden.

Khessibi, M. 1985. Etude sédimentologique des affleurements permiens du Djebel Tebaga de Médenine (Sud-Tunisien). Bull. Cent. Rech. Explor. -Prod. ElfAquitaine, 9, 2, 427-464.
Kochansky, V. 1975. Die Fusulidengattungen Jugoslowiens und die neu aufgestellten Taxa.Geol. Vjesn., 28,401-407.

Kochansky, V. \& Ramovs, A. 1978. Das Paläozoikum in Kroatien. Oster. Akad. Wiss. Schr. Erdwiss. Kommis, ,3, 235-240.

Kozur, H. 1978. Beitràge zur Stratigraphie des Perms. teil II: Die Conodontenchronologie des Perms. Freiberger Forsch., C334, 85-161.

Kozur, H. 1985. Neue Ostracoden-Arten aus dem Oberen Mittelkarbon (Höheres Moskovian), Mittel-und Oberperm des Bükk-Gebirges (N-Ungarn), Geol. paläont. Mitt. Innsbruck, 2, 1-145.

Leven, E. Y. 1967. Stratigraphy and fusulinids from Pamir deposits. Akad. Nauk SSSR. geol. Instit., Publ. Nauka, 1224 (in Russian).

Leven, E. Y. 1981. Permian Tethys stage scale and correlation of sections of the Mediterranean-Alpine fold belt. IGCP 5 Newsl., 3, 100-111.

Lys, M., Colchen, M., Bassoulet, J. -P., Marcoux, J. \& Mascle, G, 1980. La biozone à Colaniella parva du Permien supérieur et sa microfaune dans le bloc calcaire exotique de Lamayuru, Himalaya du Ladakh. Rev. Micropaléont., 23, 2, 76-108.

Masse, J. -P. 1976. Les calcaires urgoniens de Provence (Valanginien-Aptien inférieur): stratigraphie, paléontologie, les paléoenvironnements et leur évolution. Thèse Univ. Aix-Marseille II, 1-445.

Melnyk, D.H. \& Maddocks, R. 1988a. Ostracode biostratigraphy of the Permo-Carboniferous of Central and North-Central Texas, Part I: paleonenvironmental framework. Micropalaeontology, 34, 1. 1-20.

Melnyk, D.H. \& Maddocks, R. 1988b. Ostracode biostratigraphy of the Permo-Carboniferous of Central and North-Central Texas, Part II; ostracode zonation. Micropalaeontology, 34, 1, 21-40.

Miklukho-Maclay, A.D. 1958. On the subdivision in stages of Permian marine deposits of southern regions of U.S.S.R. DokI. Akad. Nauk SSSR, 120, 1, 175-178 (in Russian).

Miklukho-Maclay, A.D. 1963. The Upper Paleozoic of Soviet Central Asia. Leningrad Univ. Press, 1-327.

Minato, M., Kato, M., Nakamura, K., Hasegana, Y., Choi, D.R. \& Tazawa, J. I. 1978. Biostratigraphy of Japan. J. Fac. Sci. Hokkaido Univ., 4, 18, 1-2, 11-47.

Nakazawa, K. \& Kapoor, H.M. 1977. Correlation of the marine Permian in the Tethys of Gondwana. $I V$ int. Gondwana Symp., Calcutta, 1977, 409-419.

Newell, N.D., Rigby, J. K., Driggs, A., Boyd, D.W. \& Stehli, F.G. 1976. Permian Reef Complex, Tunisia. Brigham Young Univ. geol. Stud., 23, 1, 75-112.

Noe, S. U. 1987. Facies and paleogeography of the marine Upper Permian and of the Permian-Triassic boundary in the southern Alps (Bellerophon Formation, Tesero Horizon). Facies, 16, 89-142.

Oertli, H.J. 1971. The aspects of ostracode faunas - a possible new tool in petroleum sedimentology. Bull.Cent. 
Rech. Pau-SNPA, 5 supp., 137-151.

Pasini, M. 1981. Note preliminare su una fauna ad ostracodi dei livelli della formazione a Bellerophon delle Dolomiti. Riv. ital. Paleont., 87, 1, 1-22.

Pérès, J.M. \& Picard, J. 1964. Nouveau manuel de bionomie benthique de la Mer Méditerranée. Rec.Trav. Stat.Marine Endoume, 31, 47, 1-137.

Peterson, R.M. \& Kaesler, R.L. 1980. Distribution and diversity of ostracode assemblages from the Hamlin Shale and the Americus Limestone (Permian, Wolfcampian) in Northeastern Kansas. Univ. Kansas paleont. Contr., 100, $1-26$.

Plaziat, J. -C., 1984. Le domaine pyrénéen de la fin du Crétacé à la fin de l'Eocéne: stratigraphie, paléoenvironnements et évolution paléogéographique. Thèse. Univ. Paris Sud. 1-1362.

Razgallah, S., Chaouachi, M.C., Vachard, D. \& M'Rabet, A. 1987. Rôle des algues Tubiphytes et Archaeolithoporella dans l'édification des récifs du Permien supérieur du Djebel Tebaga, Sud de la Tunisie. 8th IAS reg. Meet. Sediment., Tunis 87, 422-423.

Ross, C.A. \& Ross, J.R.P. 1985. Carboniferous and Early Permian biogeography. Geology, 13, 27-30.

Schneider, G.F. 1948. The ostracod fauna from the Upper Permian deposits. (Tatarian and Kazanian stages) in the oil and gas bearing regions of the USSR. Trudy vsesoj. naucn-issled. geol. Inst, 31, 21-48.

Skinner, J.W. 1969. Permian foraminifera from Turkey. Univ. Kansas paleont., Contr., 36, 1-14.

Skinner, J.W. \& Wilde, G.L. 1966. Permian fusulinids from Sicily. Univ. Kansas paleont. Contr., 1-16.

Skinner, J.W. \& Wilde, G.L. 1967. Permian foraminifera from Tunisia. Univ. Kansas paleont. Contr., 30, 1-22.

Sohn, I.G. 1961. Paleozoic species of Bairdia and related genera. U.S. geol. Surv. prof. Pap., 330-A, 1-105.

Sohn, I.G. 1982. Biostratigraphic evaluation of the Carboniferous and Permian ostracodes of Texas. In: Maddocks, R.F. (edit.), Texas Ostracoda. Univ. Houston Dept. Geosci., 103-109.

Sohn, I.G., 1983. Ostracodes of the "Winifrede Limestone: (Middle Pennsylvanian) in the region of the proposed Pennsylvanian system stratotype, West Virginia. Bull. amer. Paleont., 84, 316, 1-53.

Termier, H. \& Termier, G. 1979. Histoire de la Terre, 430pp, Presses Universitaire de France, Paris.

Termier, H., Termier, G. \& Vachard, D. 1977. Monographie paléontologique de affleurements permiens du Djebel
Tebaga (Sud Tunisien). Palaeontographica, A., 156, 118.

Urasina, E.A. \& Zekina, I.U.L. 1970. Marine ostracods from the Lower Kazanian Volga-Karna interfluve. Dok I. Akad. Nauk SSSR, 194, 4, 909-911 (in Russian).

Vachard, D. 1980. Téthys et Gondwana au Paléozoïque supérieur: les données afghanes; biostratigraphie, micropaléontologie, paléogéographie. Doc. Trav. IGAL, 2, 1-463.

Vachard, D. 1985. Remarques sur les Dasycladales (algues varteso du Permien supérieur du Djebel Tebaga. Actes prem. Congr. natl.Sci. Terre, Tunis 1981, 1, 271-281.

Vachard, D. \& Razgallah, S. 1988. Survie des genres Tharama et Renalcis (épiphytales, algues problématiques) dans le Permien supérieur du Djebel Tebaga. C.R. Acad. Sci.(Paris), 306. 1137-1140.

Vachard, D. \& Razgallah, D. (in prep.), Su l'âge des séries permiennes du Djebel Tebaga (Tunisie).

Wang, S. 1978. Late Permian and Early Triassic ostracods of western Guizou and northeastern Yunnan. Acta paleont. sinica, 17, 3, 277-312 (in Chinese).

Wasfi, S., El Sweify, A. \& Abdelmalik, W. 1982. Carboniferous-Jurassic microfauna from the northern part of the Gulf of Suez, Egypt. Cah. Micropaléont., 3, 89121.

Weissbrod, T. 1969. The Paleozoic of Israel and adjacent countries; part 1: the subsurface Paleozoic stratigraphy of Southern Israel. Geol. Surv. Israel Bull., 47, 1-23.

Whatley, R.C. 1983. The application of ostracoda to paleoenvironmental analysis. In: Maddocks, R.F. (edit.), Applications of Ostracoda. Univ. Houston Dept. Geosci., 51-77.

Whatley, R.C. 1988. Population structure of ostracods: some general principles for the recognition of palaeoenvironments. In: De Deckker, P., Colin J. -P. \& Peypouquet, J. -P. (edits.), Ostracoda in the Earth Sciences, 244-256, Elsevier.

Wilde, G.L. 1975. Fusulinid defined Permian stages. In: Permian exploration boundaries and stratigraphy. West Texas Geol.Soc.\& Permian Basin Sect. SEPM Publ., 75 65, 76-83.

Ziegler, A.M., Scotese, C.R., McKerrow, W.S., Johnson, M.E., \& Bombach, R.K. 1979. Paleozoic paleogeography. Ann. Rev. Earth planet. Sci., 7, 473-502. 